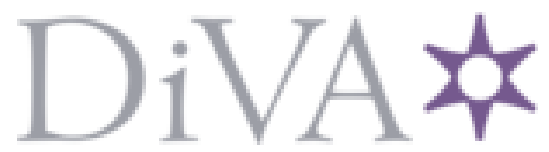

http://www.diva-portal.org

\title{
Postprint
}

This is the accepted version of a paper published in Names: A Journal of Onomastics. This paper has been peer-reviewed but does not include the final publisher proof-corrections or journal pagination.

Citation for the original published paper (version of record):

Grimbeek, M. (2016)

Wholesale Apocalypse: Brand Names in Margaret Atwood's Oryx and Crake.

Names: A Journal of Onomastics, 64(2): 88-98

http://dx.doi.org/10.1080/00277738.2016.1159448

Access to the published version may require subscription.

N.B. When citing this work, cite the original published paper.

Permanent link to this version:

http://urn.kb.se/resolve?urn=urn:nbn:se:kau:diva-40725 


\section{Wholesale Apocalypse: Brand Names in Margaret Atwood's Oryx and Crake}

Marinette Grimbeek

Karlstad University, Sweden

Coinages pervade Margaret Atwood's post-apocalyptic novel Oryx and Crake (2003). Most of the neologisms in the novel denote corporations and their products and form part of a thoroughgoing critique of consumerism. The coinages are jarringly hyperbolic and their orthography often evokes contrary connotations. However, in the thematic context of the novel, coining practices follow certain patterns and function as effective, if ambiguous, satirical tools. On one level, the practice of branding is thoroughly satirized. On another, however, the neologisms point to both the limitations and possibilities of satire when dealing with the themes addressed in the novel: commoditization, environmental damage on a planetary scale, and a vision of the imminent end of humanity itself.

KEYWORDS: Margaret Atwood; satire; brand names; literature; consumerism 
Oryx and Crake (2003), the first novel of Margaret Atwood's MaddAddam trilogy, is set in a near future in which current environmental concerns, as well as societal and biotechnological developments, have taken on decidedly dystopian dimensions. ${ }^{1}$ This article explores the notion that Atwood's criticism of current trends finds expression in a kind of Orwellian Newspeak, as is, for example, manifest in the seemingly incongruous brand names used in the novel. Atwood's coinages are discussed by first briefly showing the significance of different types of naming in the novel. Next the different categories of corporate names and related coinages in Oryx and Crake are considered. These include coined names pertaining to the Internet and online gaming, and the names of bioengineering corporations and the products they develop (cosmetic procedures, foodstuffs, as well as new, spliced species). Neologisms fulfil structural, thematic, and stylistic functions in the novel, and these are exemplified in the discussion. In conclusion, the manner in which these hyperbolic coinages simultaneously highlight the limitations and possibilities of satiric coinage as means of critique is explored.

\section{Naming in Oryx and Crake}

Through much of the post-apocalyptic narrative of Oryx and Crake, Jimmy/Snowman, the protagonist, believes himself to be the last surviving human: his only companions are the Crakers, humanoid bioengineered beings designed as the ecofriendly replacements of humans. The apocalyptic event of the MaddAddam trilogy is a pandemic engineered to cause the demise of humanity, and to thus pave the way for the Crakers. The apocalypse forms a chasm in the narrative, a break that is underscored both onomastically, and through the tense of narration.

The novel comprises two interwoven timelines: the post-apocalyptic present-tense narrative only spans a few days and is alternated with much longer sections consisting of Snowman's flashbacks to his pre-apocalyptic life. To mark the difference between his pre- 
and post-apocalyptic existence, Jimmy takes the name Snowman after the catastrophe, and refers throughout to his previous self in the third person. He derives "bitter pleasure" from the adoption of this "dubious label" at a time when climate change has rendered snow obsolete in North America (Atwood, 2003a: 7). At first he describes the name as a shortened form of Abominable Snowman, a figure "existing and not existing" (Atwood, 2003a: 7), and therefore an appropriate name for perhaps the last remaining human being. Much later in the novel, Snowman realizes:

Maybe he's the other kind of snowman, the grinning dope set up as a joke and pushed down as an entertainment, his pebble smile and carrot nose an invitation to mockery and abuse. Maybe that's the real him, the last Homo sapiens - a white illusion of a man, here today, gone tomorrow, so easily shoved over, left to melt in the sun, getting thinner and thinner until he liquefies and trickles away altogether. As Snowman is doing now. (Atwood, 2003a: 224)

Although he deliberately chooses a name with a (to him) clear denotation, Snowman thus comes to realize that the more conventional sense of his name is more apt in his situation, especially with the added connotation of a snowman as a type of fool. This dissonance between denotation and possible connotations is characteristic of the naming practices in the novel, and is especially prominent in relation to its treatment of brand names, as will be seen shortly.

Snowman is not the only character who changes his name in this novel. Members of the MaddAddam group, for instance, adopt the names of extinct species; Oryx and Crake, the two title characters, bear such names. Amanda Payne's reinvention of herself hinges on the rejection of her original name, Barb Jones, whereas the Crakers are playfully named after important historical figures like Abraham Lincoln, Madame Curie, and Sojourner Truth. The significance of charactonyms in Atwood's oeuvre has usually been noted in connection with her earlier acclaimed dystopian novel The Handmaid's Tale (1985). ${ }^{3}$ While charactonyms are not my central concern here, their prominence in Atwood's novels in general, and in Oryx and Crake in particular, illustrates the importance of names and naming in her work. 
Many of the references to names and naming in the MaddAddam trilogy share another trait: they are explicit and reflective on a metatextual level. In Oryx and Crake, MaddAddam is an endonym used by a group of anti-corporation bioterrorists. Members of the group stay in touch through the Extinctathon game. The slogan of the game refers to naming too: "Adam named the living animals, MaddAddam names the dead ones" (Atwood, 2003a: 80). The game itself requires players to correctly guess the name of a recently extinct species by analyzing its "Phylum Class Order Family Genus Species," and finally determining "the habitat and when last seen, and what had snuffed it" (Atwood, 2003a: 80). The palindromic name MaddAddam, with its doubled letters and internal capitalization, follows the same pattern as many of the coined brand names in the novel. In addition to conforming to the patterns of coinage used within the novel, this also suggests that Atwood plays with the notion of the commodification of literature or art as such. Both the final novel and the trilogy as a whole are entitled MaddAddam - confirming that coinage is not incidental, but integral to the trilogy.

\section{Coining Practices}

“Alternative universes," as Terry Eagleton recently succinctly observed, "are really devices for embarrassing the present, as imaginary cultures are used to estrange and unsettle our own" (2015: n.p.). Oryx and Crake does exactly this. Coinage is one variety of invention, and in a sense, speculative fiction itself may be seen as an elaborate coining practice, comprising invented scenarios. In Atwood's novel the near-future world of the text is always to be seen in relation to present concerns. Quite simply, despite its near-future setting the novel is a commentary on the historical circumstances of its origin. The reasons given in the novel for the deterioration from our world to the pre-apocalyptic setting are almost always connected to 
an all-pervasive commercialization, vividly represented by the ubiquitous and often absurd brand names coined before the pandemic struck.

Coinage is manifest on different levels in the novel: the plot unfolds in an invented, near-future world; this near-future world abounds with coined names to denote new technologies and products; and the protagonist regularly coined terms in his marketing job prior to the pandemic. In the pre-apocalyptic world of the novel, environmental destruction and climate change have taken on catastrophic proportions. This, in turn, has led to vast inequalities in society, manifest in the segregation of cities into Compounds, inhabited by the privileged, and pleeblands, where the less-advantaged "pleebs" (slang for 'plebeians') lead a precarious existence. Multinational corporations have become de facto governments, and individuals are consumers, rather than citizens. The pre-apocalyptic consumer culture of the novel is an extrapolation of the brand-saturated postwar American culture examined by Friedman (1991), but Atwood's narrative is not so much marked by the inclusion of existing brand names, as by the pervasive coinage of new ones.

Commercial interests trump everything else in the world of Oryx and Crake. Intellectual endeavor tends to be concentrated on profitable fields of inquiry, such as bioengineering. The only place afforded "word people" (Atwood, 2003a: 25) like Jimmy is in the marketing of pharmaceutical miracle products to gullible or desperate customers. In his copywriting job at a minor biotechnological corporation, called AnooYoo, Jimmy flogs "pills to make you fatter, thinner, hairier, balder, whiter, browner, blacker, yellower, sexier, and happier. It was his task to describe and extol, to present the vision of what —oh, so easily! could come to be" (2003a: 248). Branded products thus hold the promise of improvement, but these improvements are cosmetic only and fail to address the real problems faced by this society. 
As a "wordserf” (Atwood, 2003a: 253), Jimmy invented words like "tensicity, fibracionous, pheromonimal — but he never once got caught out. His proprietors liked those kinds of words in the small print on packages because they sounded scientific and had a convincing effect" (2003a: 248-49). Jimmy comes to see coinage as a "challenge" and remembers wondering "how outrageous could he get, in the realm of fatuous neologism, and still achieve praise?" (2003a: 250). Arguably, Atwood is walking the same tightrope as her character in coining her brand names, but in Orwellian terms these "outrageous" coinages may be seen as examples of a kind of Newspeak. Characteristic of Orwell's Newspeak is "doublethink," which entails "holding two contradictory beliefs in one's mind simultaneously, and accepting both of them" (2013 [1949]: 244). In Oryx and Crake, corporation names that appear to purposefully invite mockery include CorpSeCorps, the brutal security agency that services other corporations; as well as OrganInc, HelthWyzer, and RejoovenEsense, the names of malevolent biotechnological corporations. Yet, the doublethink practiced by the characters seems largely unavailable to readers: the names Atwood gives to corporations and their products abound in purposeful misspellings and obvious contradictions, while ubiquitous capital letters leave readers uncertain as to their pronunciation.

AnooYoo is typical of the corporation names used in the novel. It is a compound containing internal capitalization, and doubled letters substitute conventional orthography. The name suggests "a new you" and this is how it is pronounced in the audiobook version of the novel read by Campbell Scott (Atwood, 2003b). The written word, however, also contains an emphatic and contradictory "noo," reminding readers that the miracle cures promoted under this brand name are ineffective. Elaine Showalter identifies Atwood's “sappy double 'o' coinages” with a criticism of primarily Americanized consumerism, and accordingly as a disdainful representation of American pronunciation (2003: 35). On the contrary, it seems this doubling strategy (after all not restricted to vowels) fulfils a much more mundane function. 
Brand names can only be registered as trademarks when they are sufficiently distinctive.

Although the duplication of the vowel $\mathrm{O}$ is interesting in the light of Room's observation that this specific letter is "specially favoured" when it comes to trade names (1994: 193), in Atwood's novel the naming of products, websites, and corporations seems to follow the general principle of distinctiveness in branding. As a result many coinages incorporate distinguishing orthographic substitutions, capitalizations or duplications - strategies readers should recognize from their everyday encounters with brand names.

\section{Wholesale Apocalypse}

Although the naming practices used in the novel are familiar, there are often jarring disparities between their connotations and denotations. Through their incongruity brand names become even more prominent in the narrative, and in turn underline the thematic significance of commercialization. Christopher Palmer describes the coinages in the novel variously as "banal-cheery," "silly," and "nasty" (2014: 166). Invented names referring to the Internet are a case in point. The vices of the pre-apocalyptic world are reflected in the names of the websites visited by characters. Pornographic sites, for example, are named Tart of the Day, Superswallowers, and HottTotts. Alongside these sardonically labeled websites are the names given to the multiplayer online games played by a teenaged Jimmy and his best friend Crake (e.g. Extinctathon, Three-Dimensional Waco, Barbarian Stomp, and Kwiktime Osama). There are also "animal snuff sites" (Atwood, 2003a: 82) like Felicia's Frog Squash and the Queek Geek Show, as well as broadcasts of mutilations, assisted suicides, and executions (transmitted on websites named alibooboo.com, hedsoff.com, nitee-nite.com, shortcircuit.com, brainfrizz.com, and deathrowlive.com). These hyperbolic names criticize the banality of the practices they denote, and are part of the novel's larger satiric polemic against cultural decline. 
A large group of coinages relate to biotechnological corporations and their products. These names are typically ambiguous. Most of the coinages in Oryx and Crake may be classified as "descriptor" or "suggestive" names according to Danesi's categorization of brand names (2011), but often the descriptive and suggestive functions contradict each other through deliberate dissonance between spelling and pronunciation. Because they are coinages, there is no orthoepic tradition to appeal to and inherent ambiguity cannot be resolved. Confusingly, therefore, a single name can have euphemistic and dysphemistic connotations, with the names of fertility agencies like Infantade and Foetility being good examples. Said out loud, Infantade appears to describe "infant-aid," likely referring to "conception assistance," but its spelling is suggestive of intifada, used to denote a legitimate uprising against authority (Arabic, 'shaking off'). In addition the -ade ending of the name echoes those of registered trademarks like Lucuzade ${ }^{\circledR}$, Gatorade ${ }^{\circledR}$, or Powerade ${ }^{\circledR}$, all denoting energy drinks, thereby perhaps implying that conceiving is as easy as buying a consumable product off a supermarket shelf. The juxtaposition is even more pointed in the second example. In writing, Foetility, with its -ity suffix, seems to describe an abstract state or condition related to foetus, perhaps meaning "being pregnant." In pronunciation, however, the name recalls both fertility and futility - antonyms in the context of fertility agencies.

These types of dissonant corporation names are presumably the ones Showalter rallies against in her review of Oryx and Crake, when she remarks that "Atwood's satire and her playfulness don't always sort well with probability. She does not have Amis or DeLillo's gift for satiric coinage" (2003: 35). Given, however, the importance of words, names and naming in the novel, these ridiculous brand names and their very obvious contrary connotations can be seen as commentary on the cynical exploitation of human fears of ageing, illness and death which lurks behind their development. Further, the brand names are orthographically presented in such a way that they, for better or worse, cannot be ignored; they are "obviously 
cynical, over the top" and "exhibit their dreamed-up-ness almost as a badge of authenticity" (Cooke, 2006: 117). Far from showing a lack of "gift for satiric coinage" on the part of the author, their very banality forms an essential component of the satirical critique of consumerism presented in Atwood's novel.

Most of the corporation names form contradictory puns. Ostensibly referring to the "corporation security corps," CorpSeCorps of course includes the word corpse. Here too there is some uncertainty as to pronunciation. The name could conceivably be said "corps-seccorps," but Scott opts for "corpse-corps" in his recording of the text (Atwood, 2003b). The brutal methods employed by its guards lead to deaths and corpses, further emphasized by their nickname: Corpsmen. The hegemonic power of the CorpSeCorps does not just include providing security, but also encompasses controlling the financial system used in the Compounds through the Corpsbank. The neologistic compound Corpsbank exemplifies the central premise of the novel-late capitalism is intimately connected to death and extinction - and this point is made all the clearer when the first syllable of these compounds is pronounced as "corpse," as is done in the audiobook. The possibility that readers may pause to consider the pronunciation of coinages adds to their dissonance: they are internally contradictory and tend to disrupt the reading process.

Each corporation is located in its own, relatively safe, gated community, replete with malls, offices and laboratories, cafeterias, and housing for the staff, as well as schools for their children. By using the names of corporations as adjectives, their pervasive reach in the lives of Compound residents is highlighted. The HelthWyzer Compound includes, for example, the HelthWyzer Public School, also known as HelthWyzer High. A line of products known as HelthWyzer Own Brand is produced at the Compound. Ironically, HelthWyzer products have very little positive impact "health-wise," as the corporation develops and spreads new diseases to be able to sell the cures. One of its subsidiaries is called NooSkins, bringing to 
mind both "new skins" in pronunciation and "no skins" (and perhaps "noose") in writing. This ambiguity is strengthened by the name of one of their products: the NooSkins BeauToxique Treatment. Through the use of internal capitalization, the word BeauToxique does not just recall "beauty" and "beau," but also "Botox ${ }^{\circledR} "$ and "toxic."4

New technologies necessitate new names, and quite a few of the coinages in Oryx and Crake name new animal splices which originated from the heady time when "create-ananimal was so much fun" (Atwood, 2003a: 51). Unlike the capitalized brand names, animal names commonly take the form of lowercase portmanteau words or morphophonological combinations that indicate the ancestors of the new species. Names of animal splices include snats, hissing combinations of snake and rat; rakunks, raccoon-skunk splices; vicious wolvogs, a cross between wolves and dogs developed for the CorpSeCorps; kanga-lambs, a "splice that combined the placid character and high-protein yield of the sheep with the kangaroo's resistance to disease and absence of methane-producing, ozone-destroying flatulence" (Atwood, 2003a: 292); and bobkittens, smaller versions of the bobcat, designed to control feral cat populations. The dangerous pigoons, huge pigs developed as the hosts for multiple human organs, are an exception to this naming practice. Pigoon is just a nickname, revealed in The Year of the Flood to be short for "pig balloon, because they were so big" (Atwood, 2009: 221). As if to accord them more-than-animal status, the word pigoon is consistently capitalized from the middle of the third novel (from Atwood, 2013: 276), after the surviving humans have entered into a truce with these transgenic pigs. Capitalization, or the lack thereof, is therefore potentially significant in the trilogy. The author's choice not to treat the names of spliced animals in the same way as those of all other biotechnological products appears to make a larger ethical point: although genetic manipulation is possible, life itself cannot be branded. 
Another category of brand names used in the novel are those of bioengineered foods. Most of these names are formed according to similar patterns as the names of corporations, with omnipresent capitalization, doubled letters, and possibly contradictory connotations, depending on whether they are read silently or pronounced out loud. Many reflect the scarcity of natural resources and denote soy-based replacements for meat and dairy. Examples include Sveltana No-Meat Cocktail Sausages; the SoyOBoy range of burgers, sardines, and wieners; CrustaeSoy, a type of artificial, soy-derived shrimp (evoking crustacea, the shellfish family); and SoYummie Ice Cream, a soy-based product produced by HelthWyzer. Happicuppa ("happy cuppa") genetically modified coffee beans have replaced other kinds of coffee. While coffee traditionally had to be picked by hand because beans do not ripen simultaneously, the new, bioengineered variety "was designed so that all of its beans would ripen simultaneously, and coffee could be grown on huge plantations and harvested with machines" (Atwood, 2003a: 179). As a result laborers in the coffee industry lost their livelihood, and worldwide resistance led to the fighting of "gen-mod coffee wars" (2003a: 178). Drinking a Happicuppuchino is thus aything but a happy occasion.

In the pre-apocalyptic world chicken is scarce and an engineered replacement, called ChickieNobs, is increasingly being consumed. ChickieNobs consist of edible chicken parts, grown in laboratories. The specimen Jimmy sees grows chicken breasts only and looks like a "large bulblike object that seemed to be covered with stippled whitish-yellow skin. Out of it came twenty thick fleshy tubes, and at the end of each tube another bulb was growing" (Atwood, 2003a: 202). Shocked, Jimmy realizes that it has no head, and a lab assistant shows him the "mouth opening at the top" where it is fed; the creature has "no eyes or beak or anything, they don't need those" (2003a: 202). The name ChickieNob is thus euphemistically misleading: the engineered animal does not resemble a "chicken" (except as far as its meat is concerned) and lacks a "nob" ("head"). ChickieNob is treated as a capitalized brand name in 
the novel, as opposed to the lowercase names of the spliced animals discussed above. This confirms that the ChickieNob is so far removed from a conventional chicken as to no longer be an animal, in the usual sense.

\section{Paradice}

While biotechnology is mainly connected to dystopian visions of the future in the novel, the one ambivalent utopian endeavor in the text also relies on bioengineering. Through his ambiguously named Paradice Project (coupling "paradise" and "dice" or "dicey"), Crake intends to reinvent the world. The project is therefore aptly housed at RejoovenEsense ("rejuvenescence"), one of the most powerful corporations in the novel. Paradice is the genesis of the apocalyptic pandemic, and the coinages created in connection with this project are also some of most explicitly discussed in the novel. Many of the definitions proposed for different forms of utopia refer to the envisioned society in relation to, or in comparison with, the world inhabited by readers exposed to this vision (e.g. Sargent, 1994). In short, utopia is in the eye of the beholder: if readers deem living in a world similar to that represented in the text to be preferable to their current existence, the fictional world is experienced as eutopian (as a positive utopia); if the converse is true, readers experience the text as dystopic (as a negative utopia). By aligning Crake's eutopian vision of saving the planet from destructive human influence with the equivocal name Paradice, readers are reminded that this is just one of many possible outcomes; all results of Crake's endeavors are uncertain, and this is at best an ambiguous paradise.

Crake's vision of Paradice entails saving the planet by executing a two-part plan: designing ecofriendly replacements for humanity, and removing most of the human race to make space for their substitutes. Officially, the humanoid replacements are known as the Paradice Models, but they are called Crakers by all characters except for Crake. This is an 
eponym, rather than a brand name, used by the other characters to acknowledge Crake as the Crakers' inventor. The uncontrollable human desires for wealth and possessions that had almost driven the planet to annihilation have been eliminated from the Crakers' psychological makeup. In addition, therefore, the name is reminiscent of "Quakers," and the Crakers' engineered placidity certainly seems in line with Quaker ideals. The naming of the Crakers as such thus underlines the flaws of Crake's planned eutopia. Crake's attempt to erase human influence was only possible because of human intellect and technologies, and is therefore inherently ambiguous. The name Crakers monumentalizes Crake, and his Paradice Project is thus exposed as being neither completely selfless, nor successful in its quest to eradicate symbolic thinking. Although he is cast as the god-like creator of the Crakers, he attempts to destroy much that was valuable in humanity at the same time, including the ability to make jokes (Atwood, 2003a: 306). In the end, though, the Crakers' unanticipated proclivity for symbolism means that the joke is largely on him.

The second part of Crake's plan, the annihilation of humanity, is to be accomplished through the ironically named BlyssPluss pills (denoting "more bliss," but also reminiscent of Orwell's Newspeak intensifier doubleplus). These pills take advantage of all the vices of the pre-apocalyptic world. As Crake pedantically explains, his "aim was to produce a single pill," which:

a) would protect the user against all known sexually transmitted diseases, fatal, inconvenient, or merely unsightly;

b) would provide an unlimited supply of libido and sexual prowess, coupled with a generalized sense of energy and well-being, thus reducing the frustration and blocked testosterone that led to jealousy and violence, and eliminating feelings of low selfworth;

c) would prolong youth. (Atwood, 2003a: 294)

The pills also have a fourth, secret function, only known to investors: they "act as a sure-fire one-time-does-it-all birth-control pill, for male and female alike, thus automatically lowering the population level" (Atwood, 2003a: 294). Upon first hearing of BlyssPluss, Jimmy, as a 
marketing specialist, reflects on the brand name: "good name, too-BlyssPluss. A whispering, seductive sound. He liked it" (2003a: 296).

Unbeknown to everyone else, Crake uses the BlyssPluss pills as the vector for his engineered pandemic. In this way humanity faces the poetic justice of being destroyed by its own flaws - promiscuity and vanity. What follows is apocalypse by branding: the popularity of the pills is a direct result of the way in which they are marketed. The extremely contagious virus rapidly spreads to those who have not used the pills themselves. Crake made sure that Jimmy would be vaccinated so that he could take care of the Crakers, but other people would only survive if they were able to avoid both being contaminated and falling prey to the ensuing chaos. Authorities name the virus JUVE, an acronym for Jetspeed Ultra Virus Extraordinary. Its pronunciation echoes RejoovenEsense, thus leading Jimmy to wonder whether "they now knew something, such as what Crake had really been up to, hidden safely in the deepest core of the RejoovenEsense Compound" (Atwood, 2003a: 341). The "rejuvenation" promised by RejoovenEsense instead morphs into the deadly JUVE, and the "essence" of Crake's project, emphasized in the spelling of the corporation name, is revealed to have been the destruction of humanity.

Brand names in Oryx and Crake are not just dissonant in themselves; they play an important role in rendering the near-future setting of the novel simultaneously familiar and strange. In addition to coinages, registered trade names presumably familiar to readers are included, for example: Red Sox; Pachinko; Coke; Velcro; and Spam. These names link the world of the readers with the intradiegetic world, but are often used ironically. In the first scene of the novel, for example, Snowman wears an "authentic replica Red Sox baseball cap" (Atwood, 2003a: 4); later he manages to find an unopened can of "imitation Spam" (2003a: 152). The casualness with which the oxymoron "authentic replica" is employed, as well as the formulation "imitation Spam" (considering that Spam itself is a substitute for fresh meat), 
highlight the apparent futility of a quest for authenticity in a world largely shaped by commercial interests. Additionally, these adjectives draw attention to the pervasiveness of brands - they even survive an apocalypse.

Coinages and branding are thus stylistically prominent and thematically important. Structurally, coinage also plays a significant role. The coined names with their ubiquitous capitalization are conspicuous on the page, and sometimes, as shown above, disruptive in the reading experience. Coinages are even more noticeable when used as the titles of chapters. More than a third of the 53 chapter titles in Oryx and Crake consist of coined names: one is named after the MaddAddam organization; three are named after websites (Brainfrizz; HottTotts; Extinctathon); three more after new animal species (Rakunk; Wolvogs; Pigoons); another three after biotechnological corporations (OrganInc Farms; RejoovenEsense; AnooYoo); three after engineered foodstuffs (Sveltana; SoYummie; Happicuppa); while two refer to Crake's project (BlyssPluss; Paradice). In addition, there is a chapter named after each of the title characters of the novel; another is entitled Pleebcrawl (a portmanteau of the coinage "pleeblands" and the colloquial phrase "pub crawl"). An additional two coined chapter titles refer to higher education - the Applied Rhetoric degree Jimmy is enrolled in, and Asperger's U., the nickname of the prestigious bioengineering university Crake attends. In this manner form mirrors content: branding is pervasive in the near-future world of Oryx and Crake, and readers are already confronted with coinages in the table of contents.

\section{The Possibilities and Limitations of Satiric Critique}

At the beginning of this article it was argued that the invented brand names of Oryx and Crake criticize current trends using a type of Orwellian Newspeak. Certain strategies are repeatedly used in coining these names, such as internal capitalizations, the duplication and substitution of letters, as well as the creation of portmanteau and compound words. Coinages 
also seep into other language use, as they come to be employed in the creation of new compounds or are used as adjectives. Just as Orwell's Newspeak fits the totalitarian society he describes, Atwood's coinages seem appropriate for a society on the verge of extinction and in the last throes of commercial over-exploitation. Although the coinages tend to follow certain practices, they do not represent an organized, systematic attempt at altering language itself. The neologisms and brand names of Oryx and Crake demand readers' attention through their ostentatiousness, and they all force a type of doublethink that highlights rather than obliterates their internal contradictions, as well as the discrepancies between the purported intentions of products and their realizable effects.

Atwood's satire is characteristically ambivalent and multi-layered. In the novel, hyperbolic coinages foreground the practices of branding and marketing and the way in which language is entangled with these practices. It is as much an unscrupulous corporate world as its "word people" that are satirized. In addition, one sometimes gets the impression that the post-apocalyptic genre and its somewhat hackneyed tropes are subtly mocked throughout. While the invented brand names may be seen as symptomatic of a society hurtling toward apocalypse, they also serve to satirize commonly-held notions of apocalypse. This is a marketed apocalypse, as much as an apocalypse brought about by relentless marketing.

Coinages are instruments of the novel's pervading satire, but also point to the possible limitations of the mode in dealing with the weighty themes addressed, such as widespread commoditization, irreversible environmental damage on a planetary scale, and a vision of the imminent end of humanity. By giving the trilogy itself a coined name-MaddAddam — the novels are aligned with the branded commodities of their narratives. In this manner the practices critiqued in the novels are mimicked through the marketing and branding of the trilogy. If the intradiegetic world of Oryx and Crake is one shaped by branding, the important point here is that the novel encountered by readers is no less commodified. Through coinage, 
the role of branding is made visible in the near future of the novel. Readers, however, inhabit a commoditized world in which brand names are just as ubiquitous, although we have perhaps become desensitized to their pervasive presence. So although satiric coinage in the novel operates in a type of feedback loop, it may just give readers perspective on their own branded existence. Satire may not change the world, but it could help us understand it in a different way.

\section{Notes}

${ }^{1}$ The other volumes are The Year of the Flood (2009) and MaddAddam (2013).

${ }^{2}$ See, for example, Givner (1992); Henthorne (2005); Sisk, (1997: 109); and Templin (1993).

${ }^{3}$ Botox ${ }^{\circledR}$ itself is a registered trademark now often used generically. According to the United States Patent and Trademark Office (2015), the mark was registered in 1992 and is currently owned by Allergan Inc. - a corporation name that might well have come from Atwood's novel.

\section{Bibliography}

Atwood, Margaret. 1985. The Handmaid's Tale. Toronto: McClelland \& Stewart.

.2003a. Oryx and Crake. London: Bloomsbury.

. 2003b. Oryx and Crake. Read by Campbell Scott. New York, NY: Random House

Audio.

- 2009. The Year of the Flood. London: Bloomsbury.

- 2013. MaddAddam. London: Bloomsbury.

Cooke, Grayson. 2006. “Technics and the Human at Zero-Hour: Margaret Atwood's Oryx and Crake." Studies in Canadian Literature / Études en littérature Canadienne 31 (2): $105-125$. 
Danesi, Marcel. 2011. "What's in a Brand Name? A Note on the Onomastics of Brand Naming." Names 59 (3): 175-185.

Eagleton, Terry. 2015. “Utopias, Past and Present: Why Thomas More Remains Astonishingly Radical.” The Guardian, Oct. 16, $<$ http://www.theguardian.com/books/2015/oct/16/utopias-past-present-thomas-moreterry-eagleton> (Accessed October 21, 2015).

Friedman, Monroe. 1991. A "Brand” New Language: Commercial Influences in Literature and Culture. New York: Greenwood Press.

Givner, Jessie. 1992. 'Names, Faces and Signatures in Margaret Atwood's Cat's Eye and The Handmaid's Tale." Canadian Literature (133): 56-75.

Henthorne, Tom. 2005. 'Naming Names: Identity and Identification in Margaret Atwood's The Handmaid's Tale." Onoma 40: 105-113.

Orwell, George. 2013 [1949]. Nineteen Eighty-Four. London: Penguin.

Palmer, Christopher. 2014. “Ordinary Catastrophes: Paradoxes and Problems in some Recent Post-Apocalyptic Fictions.” In Green Planets: Ecology and Science Fiction. Ed. Gerry Canavan and Kim Stanley Robinson, 158-175. Middleton, CT: Wesleyan University Press.

Room, Adrian. 1994. NTC's Dictionary of Trade Name Origins. Rev. edn. Lincolnwood, IL: NTC Business Books.

Sargent, Lyman Tower. 1994. "The Three Faces of Utopianism Revisited.” Utopian Studies 5 (1): 1-37.

Showalter, Elaine. 2003. "The Snowman Cometh.” London Review of Books 25(14): 35.

Sisk, David W. 1997. Transformations of Language in Modern Dystopias. Westport, CT: Greenwood Press. 
Templin, Charlotte. 1993. "Names and Naming Tell an Archetypal Story in Margaret Atwood's The Handmaid's Tale." Names 41 (3): 143-157.

United States Patent and Trademark Office. 2015. Trademark Electronic Search System, $<$ http://msearch.uspto.gov/bin/showfield?f=doc\&state=4810:3nqitr.2.1 $>$ (Accessed October 31, 2015). 